\title{
Combining biochemical methods to trace organic effluent from fish farms
}

\author{
S. H. Woodcock ${ }^{1, *}$, C. Troedsson ${ }^{2,3,4}$, T. Strohmeier ${ }^{1}$, P. Balseiro ${ }^{2,4}$, \\ K. Sandnes Skaar ${ }^{2}$, Ø. Strand ${ }^{1}$ \\ ${ }^{1}$ Institute of Marine Research, Nordnesgaten 50, 5005 Bergen, Norway \\ ${ }^{2}$ UNI Research, PO Box 7810, Thormøhlensgate 55, 5008 Bergen, Norway \\ ${ }^{3}$ Ocean Bergen AS, Espelandsveien 232, 5258 Blomsterdalen, Norway \\ ${ }^{4}$ University of Bergen, Department of Biology, PO Box 7803, Thormøhlensgate 53 A/B, 5006 Bergen, Norway
}

\begin{abstract}
The substitution of fish oils and fish meal with terrestrial components in the diets of farmed fin-fish offers a unique opportunity to trace organic effluents from fin-fish aquaculture into the marine environment. In this study, we compared 3 techniques - the detection of soya DNA, fatty acids and stable isotopes - for tracing terrestrial components from fin-fish diets and fecal material passing from a coastal salmonid farm in Norway into the marine environment, i.e. seston traps and sediment, and then into benthic fauna, represented by the king scallop Pecten maximus. We detected soya in both the environment and scallops collected at farm locations, while changes in fatty acid composition and stable isotopes were detected between farm and reference locations in the seston traps and scallops, with great variation among organs in the latter. Combining the 3 techniques provided the greatest accuracy in distinguishing between scallops from farm and reference locations. Our results show that these 3 techniques offer complementary information on the incorporation of terrestrial components from fin-fish aquaculture into the local environment, and provide support for their potential use as regional environment monitors of aquaculture effluents.
\end{abstract}

KEY WORDS: Soya DNA - Fatty acids - Stable isotopes - Pecten maximus - Environmental monitoring · Aquaculture

${ }^{*}$ Corresponding author: skye.woodcock@imr.no

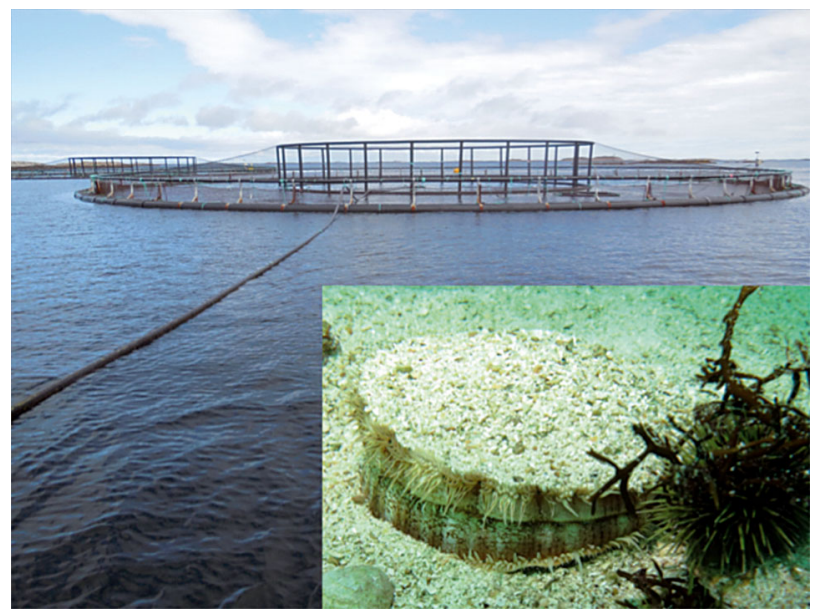

Tracing organic effluents from a coastal aquaculture farm in Norway, along a discharge pathway, into the environment and the king scallop (inset).

Photo credit: Skye Woodcock, inset: Tore Strohmeier

\section{INTRODUCTION}

As the production of farmed fin-fish continues to grow, the amount of farm effluents entering the environment correspondingly increases. Aquaculture effluents consist primarily of dissolved and particulate nutrients from fish excretion, defecation, and uneaten feed (Holmer et al. 2007). The impact that increased nutrient loadings can have on the environment depends on the characteristics of the farm (farm size, cul-

(C) The authors 2017. Open Access under Creative Commons by Attribution Licence. Use, distribution and reproduction are unrestricted. Authors and original publication must be credited. 
tivated biomass, cultivated species, feed type), environmental features (currents, local hydrodynamics, depth, water physicochemical properties, sediment type) and the type of ecosystem (García-Sanz et al. 2011). However, to fully understand this impact, it is critical to develop and validate detection tools for tracing organic effluents from aquaculture into the environment, and to characterize the magnitude, extension, and duration of its impact. Methods used to detect organic effluent include the use of tracers and biochemical techniques. While a tracer is a substance introduced into an environment or organism that can be distinguished from similar ones based on its properties, biochemical techniques, employing biomarkers, are used to assess biological effect measurements in the environment for quality assessments (Van Gestel \& Van Brummelen 1996, Martín-Díaz et al. 2004).

With increases in fin-fish aquaculture production there has been a shift in the composition of formulated feed over recent decades to include terrestrial plant ingredients as opposed to the traditionally used fish meal and fish oils (Sissener et al. 2013). Terrestrial components, such as sunflower, palm, rapeseed, corn, and soya, currently comprise more than $50 \%$ of the feed fed to fin-fish (Olsen et al. 2012, Skretting Norway 2015). Since terrestrial ingredients have different biochemical properties compared to marinesourced feeds, it is possible to develop tracers based on these differential characteristics.

Soya Glycine max is a common ingredient of formulated salmonid feed used by aquaculture farmers (Crampton et al. 2010, FAO 2012). It is a terrestrial source ingredient, which does not occur naturally in the marine environment. DNA tracers for a soyaspecific gene can be used for the identification of soya in both the sediments and in specific marine species close to the fish pen (e.g. Symondson 2002, Nejstgaard et al. 2008). Indeed, DNA tracers have been used for both detection and quantification in a range of marine taxa (e.g. Troedsson et al. 2007, Olsen et al. 2015). A TaqMan assay targeting the soya RuBisCO gene that was previously developed for Atlantic salmon digestive research (Sanden et al. 2011) might provide a highly specific assay for tracing organic effluent from fin-fish aquaculture. However, the ability of this assay to detect effluents in the water column, sediments, and inside the digestive systems of targeted species feeding on the organic effluent needs to be validated.

Organisms can have unique fatty acid (FA) profiles which are transferred from prey with little modification, offering traceable source identification (Drazen et al. 2008). Naturally, marine fish have a diet rich in unsaturated omega 3 FAs. Terrestrial plants, such as those used as a subsidy in fin-fish feeds, have high concentrations of oleic acid (18:1n-9) and linoleic acid (18:2n-6), reducing the concentrations of omega 3 FAs (Fernandez-Jover et al. 2007, 2011). FAs are involved in several cellular functions, and the variety of their structures make certain FAs useful as biomarkers (Budge \& Parrish 1998). FAs have been used to trace organic effluent from aquaculture into the environment (Van Biesen \& Parrish 2005) as well as into several species including mussels (Handå et al. 2012), urchins (White et al. 2017), and fish (Fernandez-Jover et al. 2007, 2011).

Stable isotopes (SI) are useful as both natural tracers and as a means of describing trophic structure (Fredriksen 2003, Michener et al. 2007). The SI ratio of nitrogen, $\delta^{15} \mathrm{~N}$, can be used to estimate trophic position, as the $\delta^{15} \mathrm{~N}$ of a consumer is typically enriched by 3 to $4 \%$ relative to its diet. In contrast, the SI ratio of carbon, $\delta^{13} \mathrm{C}$, changes little as carbon moves through food webs and, therefore, can typically be used to evaluate the ultimate source of carbon for an organism when the isotopic signatures of the sources are different (Post 2002). Elevated signatures of both $\mathrm{C}$ and $\mathrm{N}$ have been found in the sediments below fish farm cages due to organic effluent (McGhie et al. 2000), and differences between wild and farmed salmon have been found using nitrogen and carbon isotope ratios (Dempson \& Power 2004). Long-term exposure to organic effluent from farms can reduce the range of signatures, compared to natural variations (Lojen et al. 2005).

These 3 biochemical techniques could potentially be used to trace fish farm effluents in the marine environment as each provides different information about contamination by aquaculture effluents. FAs and SI are established bioindicators for organic effluent from aquaculture, while the detection of soya DNA is a novel approach. In terms of identification of terrestrial crops as a proxy for consumption by marine organisms, the 3 markers provide complementary information. While the DNA tracer relies on its presence or absence and is essentially a marker of recent ingestion of organic effluents from fish farms (minutes to hours, dependent on gut passage and breakdown time in samples) (Nejstgaard et al. 2003), FAs and SI indicate integrative uptake in the order of weeks to months (Paulet et al. 2006, Redmond et al. 2010) and can be used both as indicators of terrestrial matter as well as a shift in the biochemical profiles. These markers, if successful, could be used to trace both the local and regional spread of effluents from aquaculture. 

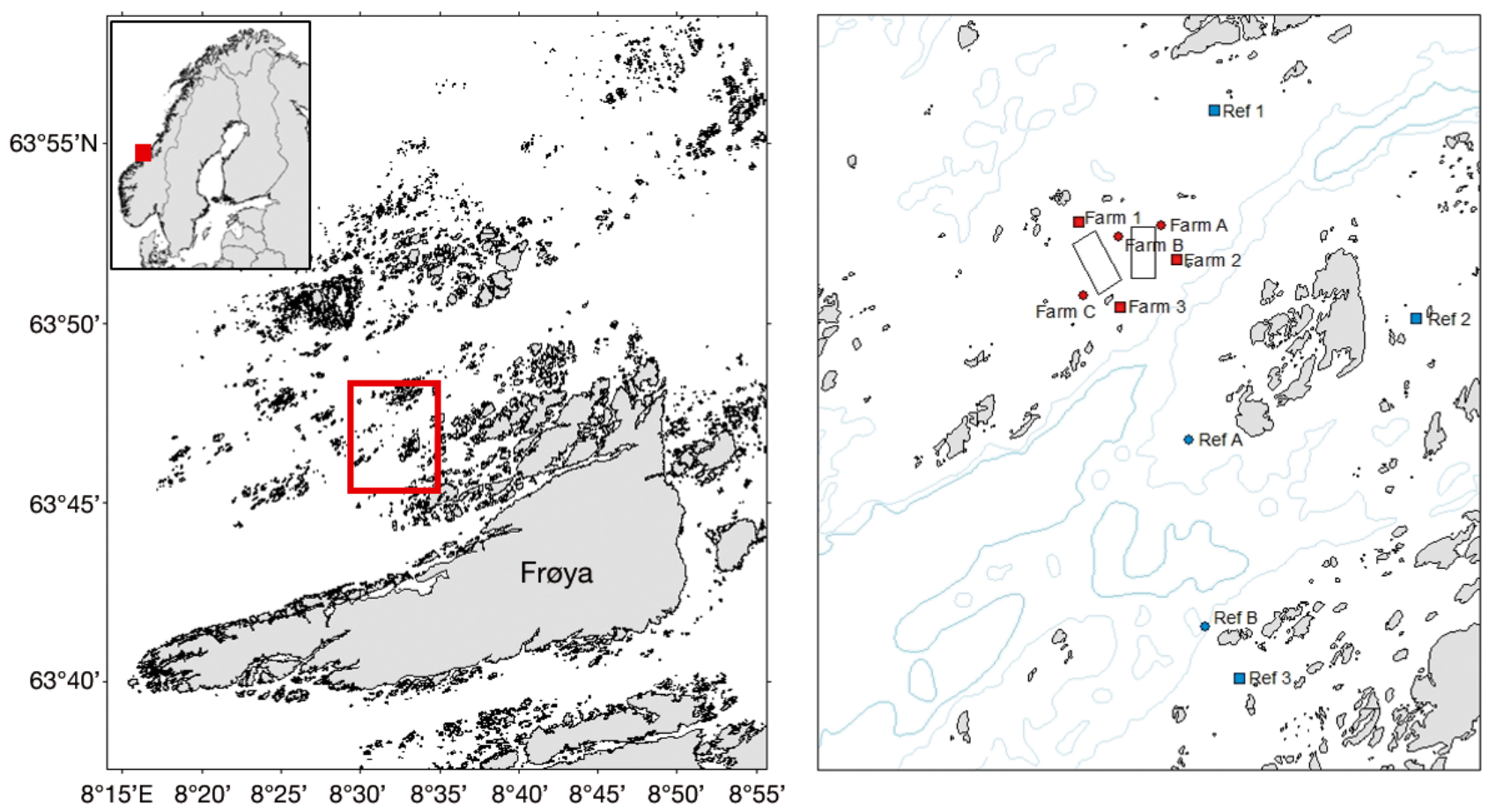

Fig. 1. Sampling locations. Left: archipelago area north of Frøya, Norway (inset). Right: sampling area with black rectangles indicating the general Rataren farming locations. Red symbols: sampling within the farm area; blue symbols: reference (Ref) locations. Squares: SCUBA sites for scallop and sediment samples; circles: seston trap placements. Depth contours are at $100 \mathrm{~m}$ (light blue) and $200 \mathrm{~m}$ (darker blue)

The dispersal of effluents from aquaculture depends on sinking rates and current velocity conditions (Bannister et al. 2016), and the amounts eventually reaching the benthos decrease with increasing distance from the farm site. The king scallop Pecten maximus is a sedentary species commonly found along the Norwegian coastline, recessed into shallow depressions in the seabed of a range of soft substrates between 5 and $60 \mathrm{~m}$ depth (Duncan et al. 2016). In outer coastal areas, the distribution of $P$. maximus overlaps with many fin-fish farm sites, both those in current operation and where expansion is expected along the Norwegian coast. If scallops are feeding on organic effluent, they could be an ideal species for determining organic effluent outfall from Norwegian fin-fish farms and its spread into the local and regional environment.

This study aims to determine if 3 different techniques, DNA, FAs, and SI, can be used to trace organic material from an aquaculture source (fish feed and fecal material) along a specific pathway, into the local marine environment (seston traps and sediment) and finally into scallop tissues. We first investigated the performance of individual techniques to determine if they can be used to distinguish between samples from aquaculture and reference locations along the discharge pathway, and secondly, we compared the pros and cons of the individual methods with regard to practical application individually and in combination.

\section{MATERIALS AND METHODS}

\section{Location and sample collection}

The study area was located in the vicinity of the salmonid farm Rataren in the archipelago north of Frøya, Norway (Fig. 1). Three farm sites at Rataren (Table 1, Fig. 1) were selected based on the depth range (10 to $25 \mathrm{~m}$ ) suitable for SCUBA diving between the islands forming the rim of the basin where the farm is situated, and slopes of soft bottom assumed to have scallops. All farm samples were collected within $200 \mathrm{~m}$ of the closest cage (Table 1, Fig. 1). Three reference sites, 1 to $3 \mathrm{~km}$ from the closest cage (Fig. 1), were selected based on distance (Table 1) and similar depth to the farm sites. All sites were sampled in August 2014. Sampling was designed to trace organic effluent. The primary effluent, fish feed and fish fecal material (sampled by hand from farmed salmon), was collected from Rata- 
Table 1. Summary of sample collection sites and analyses performed. (a) Environmental samples and (b) king scallops Pecten maximus. All samples were collected in 2014. Refer to Fig. 1 for overview of area and site location in relation to farms. DNA: soya DNA; FAs: fatty acids; SI: stable isotopes

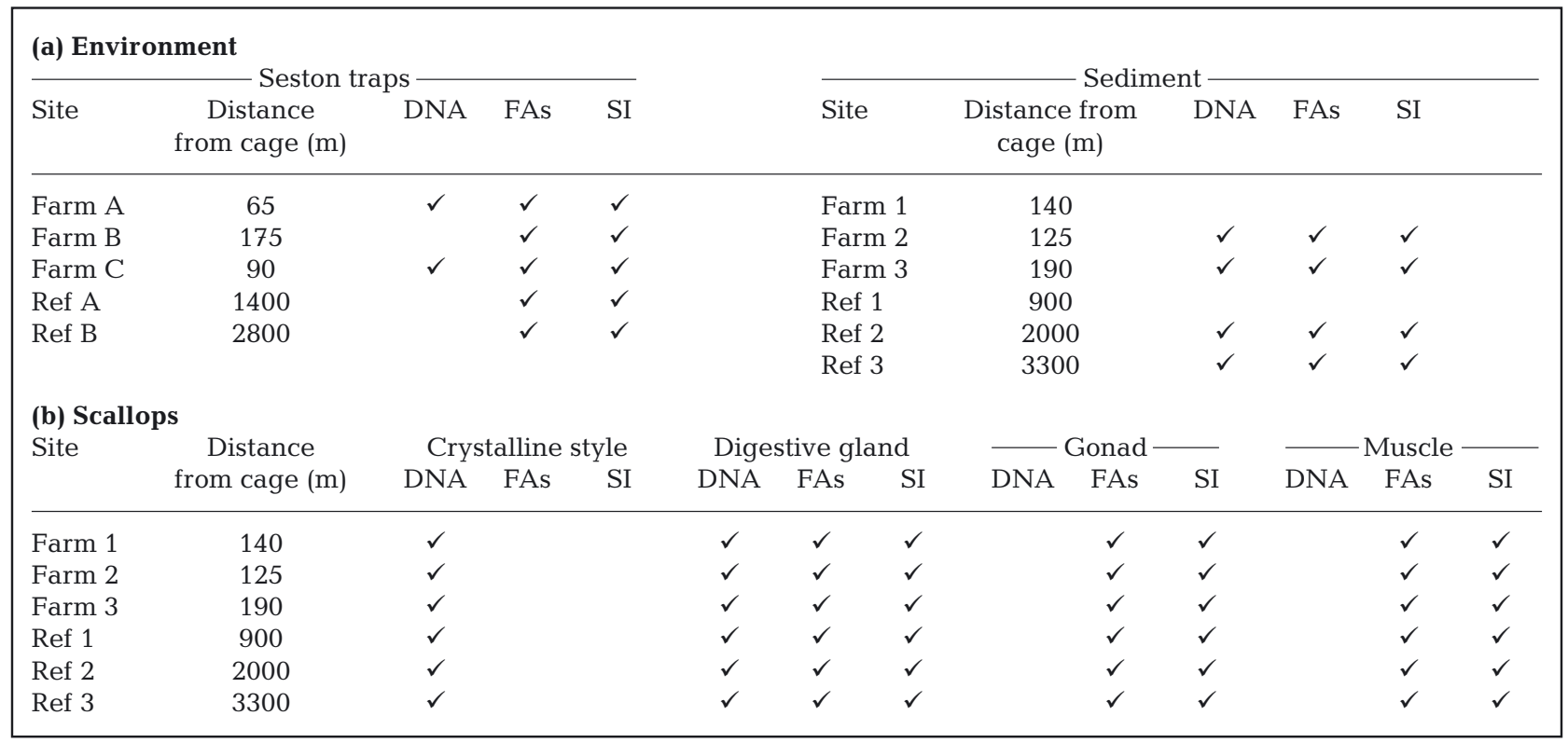

ren in August 2014 for DNA analysis, and additional feed and fecal material was collected in 2015 for FA and SI analysis. Feed and fecal materials used for DNA analysis were stored in a homogenization buffer with $12 \mathrm{mAU}$ of proteinase K (DNeasy Blood \& Tissue Kit, Qiagen).

To trace organic effluent in the environment, seston traps were deployed for $10 \mathrm{~d}$ at a depth of $25 \mathrm{~m}$ at 3 farm sites and 2 reference sites (Table 1, Fig. 1) to collect organic material settling out of the water column. During sampling, particulate matter was transferred to a container and stored frozen until analysis. A subsample was taken from 2 farm traps for DNA analysis, incubated in a homogenization buffer with $12 \mathrm{mAU}$ of proteinase $\mathrm{K}$, and genomic DNA was extracted following the manufacturer's instructions. For the remaining sample, and additional traps, particulate matter was centrifuged to separate out the solid matter, which was either refrozen for FA analysis or oven dried at $40^{\circ} \mathrm{C}$ for SI analysis.

Sediment and scallop samples were collected using SCUBA diving at depths between 10 and $25 \mathrm{~m}$. Sediment was sampled from 4 locations (Table 1, Fig. 1) and was collected using a $50 \mathrm{ml}$ conical tube to gently sample the upper surface layer $(1 \mathrm{~cm}$ depth). The sample container was then sealed before transported to the surface. Sediment samples were then transferred to pure ethanol and stored at $-80^{\circ} \mathrm{C}$. For DNA, the ethanol was removed by centrifugation prior to sediment DNA isolation. For FA and SI analysis, the ethanol was completely evaporated off by drying sediment under nitrogen evaporation. Scallops were brought to the surface where they were kept alive until dissection within 2 to $4 \mathrm{~h}$ after collection. Three scallops were collected from each dive sample site (Fig. 1). Ethanol (70\%) was used to clean dissection tools between samples to avoid cross contamination. The crystalline style and the gastric shield from the digestive gland (about $125 \mathrm{~mm}^{3}$ ) were sampled and stored in ATL buffer supplemented with $12 \mathrm{mAU}$ of proteinase $\mathrm{K}$. The remainder of the digestive gland, part of the striated muscle, and the entire gonad were additionally dissected and immediately frozen $\left(-20^{\circ} \mathrm{C}\right)$. Once back at the laboratory, the individual tissue samples were freeze dried, homogenized, and stored frozen $\left(-20^{\circ} \mathrm{C}\right)$ in glass vials for FA and SI analysis.

\section{DNA}

DNA isolation from fish feed, fish feces, seston traps, and scallop tissues were carried out using the DNeasy Blood \& Tissue Kit (Qiagen) following the manufacturer's instructions with slight modifications. Briefly, after storage at $-20^{\circ} \mathrm{C}$, samples were incubated overnight at $56^{\circ} \mathrm{C}$ with $6 \mathrm{mAU}$ of proteinase $\mathrm{K}$ extra. Each sample was also subjected to a double cleaning step with the AW1 and AW2 buffers. For the sediment samples, DNA isolation was performed in 3 
replicates $(0.6 \mathrm{~g})$ from each sample using the PowerSoil DNA Isolation Kit (MoBio Laboratories) following the manufacturer's instructions. This kit has previously been shown to be suitable for marine sediments (Lekang et al. 2015). Isolated genomic DNA was eluted in a final volume of $100 \mu \mathrm{l}$ and stored at $-20^{\circ} \mathrm{C}$ until use. For all samples, DNA concentration was measured using the Qubit ${ }^{\circledR}$ dsDNA HS Assay Kit (Life Technologies).

The soya RuBisCO gene was selected as an environmental tracer for organic effluent from aquaculture. PCR was carried out using the primers Soya Rubisco F (5'-GGG CTT ACC AGT CTT GAT CG-3') and Soya Rubisco R (5'-TGA TTT TCT TCC CCA GCA AC-3') (Sanden et al. 2011) on a C1000 thermocycler (BioRad) with the following thermal conditions: an initial denaturing step at $95^{\circ} \mathrm{C}$ for $15 \mathrm{~min}$ followed by 30 cycles of $94^{\circ} \mathrm{C}$ for $45 \mathrm{~s}, 59^{\circ} \mathrm{C}$ for $45 \mathrm{~s}$, and $72^{\circ} \mathrm{C}$ for $1 \mathrm{~min}$, and a final elongation step at $72^{\circ} \mathrm{C}$ for $1 \mathrm{~min}$. Analytical specificity was tested against a panel of genomic DNA including common species found in Norwegian waters and fish feed pellets. Positive products were cloned into a pSC-A-amp/kan plasmid following the manufacturer's instructions (Agilent Technologies). Five different clones of each product were sequenced using the BigDye Terminator 3.1 in an Applied Biosystems 3730XL capillary sequencer at the University of Bergen sequencing facility. The obtained sequences were edited to remove vector sequences and identity was determined by searching GenBank using the NCBI BLASTn tool.

The TaqMan assay was conducted using the primers and probe described by Sanden et al. (2011). The TaqMan probe (6-FAM-5'-GGG CGA TGC TAC GGC CTT GA-3'-BHQ-1) was obtained from SigmaAldrich Norway. Reactions were carried out in a final volume of $25 \mu \mathrm{l}$ containing $2 \times$ SsoAdvanced Probes Universal Supermix (BioRad), $500 \mathrm{nM}$ of each primer and probe, and $1 \mu \mathrm{g} \mathrm{ll}^{-1} \mathrm{BSA}$. TaqMan assays were run on a CFX96 RTS instrument (BioRad) with an initial denaturation step at $95^{\circ} \mathrm{C}$ for $2 \mathrm{~min}$, followed by 40 cycles of $95^{\circ} \mathrm{C}$ for $10 \mathrm{~s}$ and $59^{\circ} \mathrm{C}$ for $10 \mathrm{~s}$. The TaqMan assay primer efficiency was estimated using a dilution series of genomic DNA from fish feed pellet. All the TaqMan runs were conducted in triplicates using $1.5 \mathrm{ng}$ genomic DNA as template and included a standard curve of fish feed pellet genomic DNA diluted in $10 \mathrm{mM}$ Tris-buffer, $\mathrm{pH}$ 8. Off-shore sediments from the North Sea (Lanzén et al. 2016) were used to establish a threshold for soya RuBisCO detection in the TaqMan assay. These sediments were considered as uninfluenced by aquaculture effluents due to their large distance from the shore, providing a more conservative baseline for soya detection than reference samples closer to aquaculture facilities. These samples have also been analyzed by high throughput sequencing elsewhere, without detection of soya (Lanzén et al. 2016). Threshold detection was established 1 cycle lower than the minimum quantification cycle (Cq) value observed in North Sea samples. The TaqMan assay was considered positive if 2 out of 3 replicates were positive. A site was considered positive if 2 out of 3 samples were positive. Moreover, a scallop sample was considered positive if either the crystalline style or gastric shield was positive.

\section{FA analysis}

All samples were weighed out into thick-walled glass tubes prepared with $100 \mu \mathrm{l}$ of internal standard 19:0. Sample weights for analyses were dependent on sample types: $50 \mathrm{mg}$ freeze-dried material for diet, fecal material, and scallops (digestive gland, muscle, and gonad), and $500 \mathrm{mg}$ dried sediment. All samples were prepared using the 1-step direct methylation method (Meier et al. 2006), whereby samples were methylated using $1 \mathrm{ml}$ anhydrous methanol containing $2.5 \mathrm{M} \mathrm{HCl}$ and placed in an oven at $100^{\circ} \mathrm{C}$ for $2 \mathrm{~h}$. After cooling, methanol was evaporated using $\mathrm{N}_{2}$ gas and $0.5 \mathrm{ml}$ distilled water was added. FAs were extracted twice from the water/methanol phase with $2 \mathrm{ml}$ hexane by first mixing with a vortex and then centrifugation at $2000 \mathrm{rpm}$ for $5 \mathrm{~min}$; the hexane phase was then withdrawn using a glass Pasteur pipette. Sediment and seston trap extractions required an additional clean-up, whereby the extract was run through a Chromabond ${ }^{\circledR}$ ready-to-use solid phase extraction (SPE) cartridge glass column prior to further processing. Columns were prepared using $6 \mathrm{ml}$ hexane and the sample was run through. They were then rinsed with $3 \mathrm{ml}$ hexane and $2 \mathrm{ml}$ hexane acetate. Sediment samples were evaporated to $200 \mu \mathrm{l}$ under $\mathrm{N}_{2}$ gas.

Using splitless injection, $1 \mu \mathrm{l}$ extract was injected into a HP-5890A gas chromatograph (Agilent) with a flame ionization detector (GC-FID). The column was a $2 \mathrm{~m} \times 0.25 \mathrm{~mm}$ fused silica capillary coated with a $0.2 \mu \mathrm{m}$ thick polyethylene-glycol film (CP-Wax 52 $\mathrm{CB}$, Varian-Chrompack). Helium (99.9999\%) was used as the mobile phase at $1 \mathrm{ml} \mathrm{min}^{-1}$ constant column flow. The injector temperature was $270^{\circ} \mathrm{C}$ and the detector temperature $300^{\circ} \mathrm{C}$. The GC-FID was programmed to include a FAME standards (GLC68A from Nu-Chek Prep) every 10th sample to mon- 
itor any drift over time in the GC and identify the chromatographic peaks in the samples by comparing retention times (see Meier et al. 2006 for additional information). Peaks $<0.5 \%$ were excluded from environmental samples, while peaks $<0.2 \%$ were excluded from scallop tissues.

\section{SI analysis}

Freeze-dried tissues from the digestive gland, muscle, and gonad, along with the fish pellet and fecal material, were weighed out into tin capsules, and 0.6 to $1.2 \mathrm{mg}$ of each sample was selected for further analyses. For dried seston material, $5 \mathrm{mg}$ was weighed into tin capsules and further analyzed. Sediment was weighed out (45 mg) into silver capsules and decalcified using a washing method, whereby a small amount of $1 \mathrm{M} \mathrm{HCl}$ (5 to $10 \mu \mathrm{l}$ ) was added to the capsule and samples were allowed to effervesce for 5 to $10 \mathrm{~min}$ at room temperature. Capsules were then placed in a drying oven at $40^{\circ} \mathrm{C}$ for $20 \mathrm{~min}$ to dry. This process was repeated until effervescence was no longer observed. Samples were then left overnight to dry before being reweighed. All samples were sent to the University of California, Davis, Stable Isotope Facility. Samples were analyzed for $\delta^{15} \mathrm{~N}$ and $\delta^{13} \mathrm{C}$ using a PDZ Europa 20-20 isotope ratio mass spectrometer (Sercon). Samples were run against 5 reference materials (bovine liver: $\delta^{13} \mathrm{C}=-21.69, \delta^{15} \mathrm{~N}=7.72$; nylon 5: $\delta^{13} \mathrm{C}=-27.72, \delta^{15} \mathrm{~N}=-10.31$; glutamic acid (USGS41): $\delta^{13} \mathrm{C}=37.63, \delta^{15} \mathrm{~N}=47.6$; glutamic acid: \%C 40.81, $\delta^{13} \mathrm{C}=-16.65, \% \mathrm{~N} 9.52, \delta^{15} \mathrm{~N}=-6.8$; and peach leaves: $\left.\% \mathrm{C} 46.18, \delta^{13} \mathrm{C}=-26.12, \% \mathrm{~N} 2.88, \delta^{15} \mathrm{~N}=1.95\right)$.

\section{Statistics}

PRIMER 7 with permutational multivariate analysis of variance (PERMANOVA) (www.primer-e.com/) was used for all statistical analyses. Non-transformed data were converted to Euclidean distance matrices and performed using unrestricted permutations of the data for all tests. PERMANOVA with unrestricted permutations and a Monte Carlo test was first used to test for differences in the environmental samples, seston, and sediments between the farm and reference locations for each of the 3 biomarker techniques. For detection of soya DNA in scallop tissues, PERMANOVA was used to determine the difference between locations in each of the 2 tissues individually and in combination. For FA and SI analysis, PERMANOVAs were first used to determine the dif- ference between sample sites and then locations (reference vs. farm) for the individual scallop components, digestive tissue, gonad, and muscle, as well as in combination. For FA analysis, the full FA profile was used, as well as the 2 terrestrial markers (18:1n9 and 18:2n-6) for combined tissue analysis. Pairwise tests were performed when significant differences were detected.

Comparisons of the 3 biochemical techniques individually or in combination were achieved using canonical analysis of principal coordinates (CAP) along with cross validation (leave-one-out allocation) to determine if scallops could be classified to their original collection location. For this analysis, only the 2 terrestrial FA markers were used. Firstly, we combined the tissues within a technique to determine how well they performed individually. Secondly, using just the digestive tissues, we compared the techniques individually and in combination to determine which would produce the highest overall correct classification back to sample location (farm vs. reference). For DNA analysis of combined tissues, percentages were calculated based on whether scallops were classified as positive or negative for soya DNA.

\section{RESULTS \\ DNA}

The soya RuBisCO DNA tracer could detect soya in all the different sample types: feed pellet, fecal material, seston traps, sediment, and scallops (Tables 2 $\& 3$ ). Both seston and sediment samples collected from farm sites were positive for the detection of soya (Table 2), with significant differences found between reference and farm locations for sediment (Table 3).

The presence of soya in crystalline style could be used to identify scallops collected from farm or reference locations (Table 4). Soya detection in the gastric shield was more difficult (Table 4). However, since both these tissues represent only part of the digestive system, and organic material is unlikely to be homogeneously distributed throughout the whole digestive system (due to e.g. differential feeding and digestion), both these tissues should be treated together. Combining the tissues resulted in significant differences between locations (Table 4). Using presence or absence of soya in individual scallops, we found positive detection of soya in $100 \%$ of scallops from farm locations (Table 2, see also Table 6). Two reference scallops, however, were also positive for the soya tracer (Table 2), reducing overall correct allocation to sam- 
Table 2. Detection (+ = present, $-=$ absent) of the soya Glycine max RuBisCO gene in the sediment and king scallop Pecten maximus samples (blank if no sample taken) from reference and farm sites

\begin{tabular}{|c|c|c|c|c|c|c|}
\hline \multirow[t]{2}{*}{ Site } & \multicolumn{2}{|c|}{ - Seston traps - } & \multicolumn{2}{|c|}{$\longrightarrow$ Sediment -} & \multicolumn{2}{|c|}{$\longrightarrow$ Scallops $\longrightarrow$} \\
\hline & $\begin{array}{c}\text { Soya } \\
\text { detection }\end{array}$ & $\begin{array}{c}\% \\
\text { positive }\end{array}$ & $\begin{array}{c}\text { Soya } \\
\text { detection }\end{array}$ & $\begin{array}{c}\% \\
\text { positive }\end{array}$ & $\begin{array}{c}\text { Soya } \\
\text { detection }\end{array}$ & $\begin{array}{c}\% \\
\text { positive }\end{array}$ \\
\hline Ref 1 & & & - & 0 & - & 33 \\
\hline Ref 2 & & & - & 0 & - & 0 \\
\hline Ref 3 & & & & & - & 33 \\
\hline Farm 1 (A) & + & 100 & + & 67 & + & 100 \\
\hline Farm 2 & & & + & 67 & + & 100 \\
\hline Farm 3 (C) & + & 100 & & & + & 100 \\
\hline
\end{tabular}

Table 3. PERMANOVA of environmental differences between locations for 3 different biochemical techniques: soya DNA, fatty acid profiles and stable isotopes. MC: Monte Carlo test; significant values $(\mathrm{p}<0.05)$ are given in bold

\begin{tabular}{|c|c|c|c|c|}
\hline Source & $\mathrm{df}$ & MS & $F$ & $\mathrm{p}(\mathrm{MC})$ \\
\hline \multicolumn{5}{|l|}{ Soya DNA } \\
\hline \multicolumn{5}{|l|}{ Sediment } \\
\hline Location & 1 & 26.74 & 8.05 & $<0.05$ \\
\hline Residual & 9 & 3.32 & & \\
\hline \multicolumn{5}{|l|}{ Fatty acids } \\
\hline \multicolumn{5}{|c|}{ Seston traps } \\
\hline Location & 1 & 696.08 & 10.22 & $\leq 0.01$ \\
\hline Residual & 3 & 68.10 & & \\
\hline \multicolumn{5}{|l|}{ Sediment } \\
\hline Location & 1 & 14.02 & 0.13 & $>0.05$ \\
\hline Residual & 2 & 104.74 & & \\
\hline \multicolumn{5}{|c|}{ Stable isotopes } \\
\hline \multicolumn{5}{|c|}{ Seston traps } \\
\hline Location & 1 & 72.16 & 78.71 & $\leq 0.01$ \\
\hline Residual & 3 & 2.75 & & \\
\hline \multicolumn{5}{|l|}{ Sediment } \\
\hline Location & 1 & 6.65 & 0.41 & $>0.05$ \\
\hline Residual & 2 & 16.37 & & \\
\hline
\end{tabular}

Table 4. PERMANOVA of differences between farm and reference locations in the detection of soya Glycine max DNA in king scallop Pecten maximus tissues. MC: Monte Carlo test; significant values $(\mathrm{p}<0.05)$ are given in bold

\begin{tabular}{|lcrcc|}
\hline Source & df & MS & $F$ & $\mathrm{p}(\mathrm{MC})$ \\
\hline Soya DNA & & & & \\
$\quad$ Gastric shield & & & & \\
$\quad$ Location & 1 & 8.40 & 4.05 & $>0.05$ \\
$\quad$ Residual & 16 & 2.07 & & \\
$\begin{array}{l}\text { Crystalline style } \\
\text { Location }\end{array}$ & 1 & 108.16 & 37.48 & $\mathbf{5 0 . 0 0 1}$ \\
$\quad$ Residual & 16 & 2.89 & & \\
$\quad$ Combined tissues & & & & \\
$\quad$ Location & 1 & 116.56 & 23.51 & $\mathbf{5 0 . 0 0 1}$ \\
Residual & 16 & 4.96 & & \\
\hline
\end{tabular}

ple location (88\%, see Table 6). Sequencing analysis of the amplicons indicates that the scallops from the reference sites were indeed positive for soya.

\section{FAs}

Terrestrial markers 18:1n-9 and 18:2n6 were high in the diet and fecal material (Fig. 2a). In the environment, significant differences were found in the seston trap full FA profile (Table 3 and Table A1 in the Appendix) and 18:1n-9 and 18:2n6 profiles $\left(18: 1 \mathrm{n}-9, F_{1,3}=106.42, \mathrm{p}<0.001 ; 18: 2 \mathrm{n}-6\right.$, $F_{1,3}=57.15, \mathrm{p}<0.01$; Fig. 2a) between farm and reference locations. When taking into account the full FA profile of the sediment (Table A1), no significant difference was found between farm and reference locations (Table 3); however, there were larger amounts of 18:1n-9 $\left(F_{1,2}=4.17, \mathrm{p}>0.05\right)$ and significantly more $18: 2 \mathrm{n}-6\left(F_{1,2}=25.62, \mathrm{p}<0.05\right)$ at the farm compared to reference locations in the sediment (Fig. 2a).

Looking at the entire FA profiles of scallop tissues (Table A2 in the Appendix), there was no significant difference found between locations (farm vs. reference) for scallop digestive gland and gonad; there was, however, a difference for muscle (Table 5). Significant differences between sites were found for muscle and gonad (Table 5). Combining the 3 tissues and just looking at the 2 terrestrial markers resulted in no significant difference between locations (Table 5). CAP analysis was used to determine whether scallops could be correctly identified as being collected from the farm or reference locations using the 2 terrestrial markers. Testing the 3 tissues individually led to $>50 \%$ correct location classification: digestive tissue $55 \%$, gonad $83 \%$, and muscle $61 \%$. However, when the 3 tissues were combined, the correct classification using CAP analysis was $70 \%$ (Table 6).

\section{SI}

A significant difference in the SI ratios was found between seston traps placed at farm and reference sites; however, no differences were found in the sediment (Table 3). Seston material collected at farms showed significantly depleted $\delta^{13} \mathrm{C}$ and $\delta^{15} \mathrm{~N}$ signatures, reflective of the diet and fecal material (Fig. 2b). No significant differences were found in the sediment, although $\delta^{13} \mathrm{C}$ was depleted at the farm compared to the reference sites. 
For scallop tissues, significant differences were found between sample locations for all 3 tissues (Table 5). Using SI, scallops could be classified back to their collection location, with digestive gland and muscle providing $77 \%$ correct allocation, and gonad $66 \%$ correct allocation. Combining the 3 tissues increased the total correct classification to $83 \%$ (Table 6).
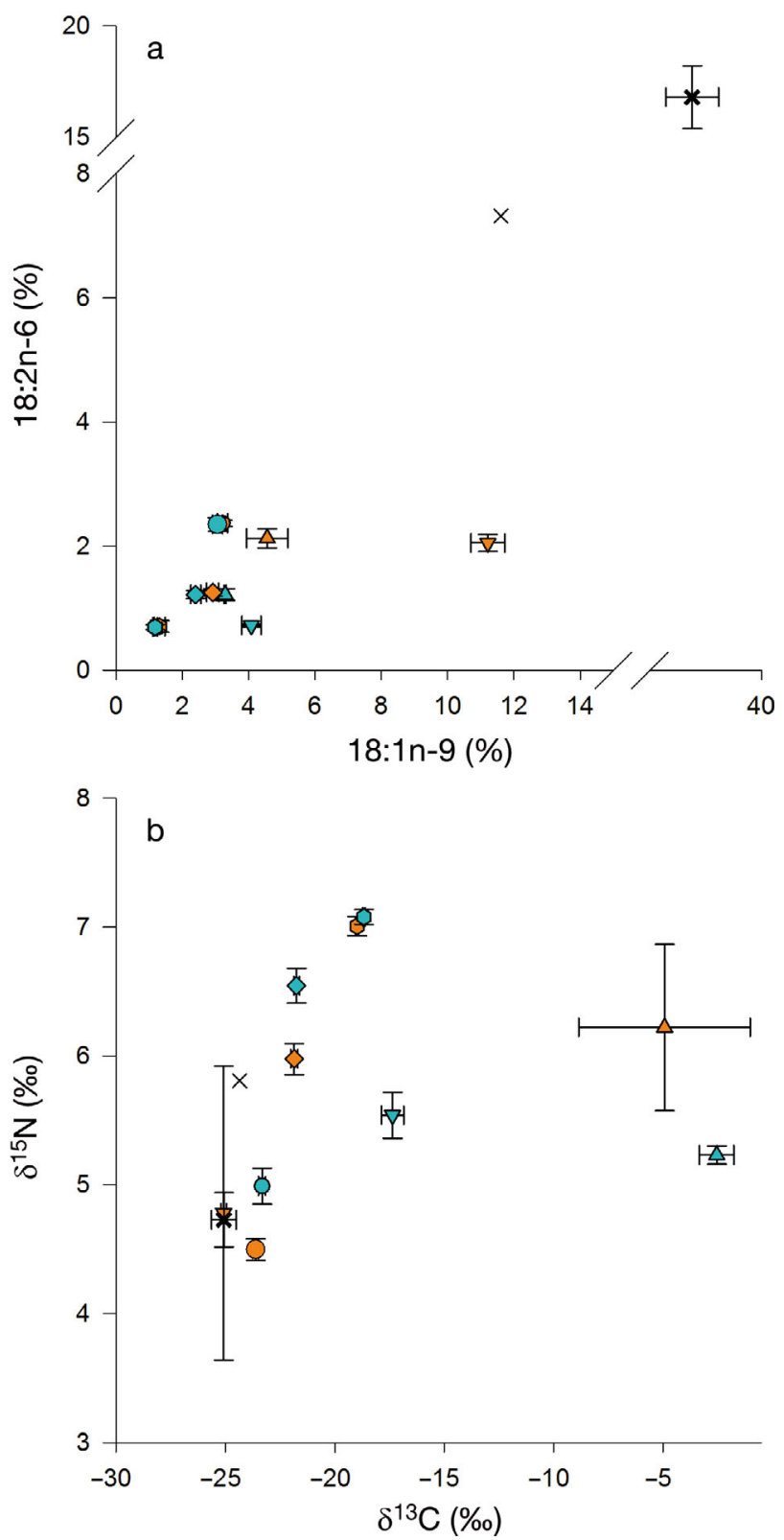

Fig. 2. Biomarkers for (a) terrestrial fatty acids 18:1n-9 and $18: 2 \mathrm{n}-6$, and (b) stable isotope ratios $\delta^{13} \mathrm{C}$ and $\delta^{15} \mathrm{~N}$. Error bars are SE. Symbols represent the source of aquaculture organic effluent, diet $\mathbf{x}$ and fecal material $\times$, and biomarkers found in environment samples seston traps $\boldsymbol{\nabla}$, sediment $\boldsymbol{\Delta}$, and king scallop Pecten maximus tissues, digestive gland $\bullet$ gonad $\bullet$, and muscle $\bullet$, sampled from farm (orange) or reference (blue) locations
Analysis of individual SI found a significant difference in $\delta^{13} \mathrm{C}$ for muscles $\left(F_{1,16}=13.60, \mathrm{p}<0.01\right)$ and a significant difference in $\delta^{15} \mathrm{~N}$ for digestive tissue $\left(F_{1,16}=9.01, \mathrm{p}<0.01\right)$ and gonad $\left(F_{1,16}=9.89, \mathrm{p}<0.01\right)$ between locations (Fig. 2b).

Table 5. PERMANOVA of the differences between sample site and location for the full fatty acid profile and stable isotopes in king scallop Pecten maximus tissues. MC: Monte Carlo test; significant values $(\mathrm{p}<0.05)$ are given in bold

\begin{tabular}{|c|c|c|c|c|}
\hline Source & $\mathrm{df}$ & MS & $F$ & $\mathrm{p}(\mathrm{MC})$ \\
\hline \multicolumn{5}{|l|}{ Fatty acids } \\
\hline \multicolumn{5}{|c|}{ Digestive gland } \\
\hline Site & 5 & 29.11 & 1.79 & $>0.05$ \\
\hline Residual & 12 & 16.28 & & \\
\hline Location & 1 & 32.72 & 1.70 & $>0.05$ \\
\hline Residual & 16 & 19.26 & & \\
\hline \multicolumn{5}{|l|}{ Muscle } \\
\hline Site & 5 & 31.93 & 4.59 & $\leq 0.01$ \\
\hline Residual & 12 & 6.95 & & \\
\hline Location & 1 & 37.55 & 2.92 & $<0.05$ \\
\hline Residual & 16 & 12.85 & & \\
\hline \multicolumn{5}{|l|}{ Gonad } \\
\hline Site & 5 & 26.06 & 3.78 & $<0.05$ \\
\hline Residual & 12 & 6.89 & & \\
\hline Location & 1 & 8.60 & 0.67 & $>0.05$ \\
\hline Residual & 16 & 12.77 & & \\
\hline \multicolumn{5}{|c|}{ Combined tissues } \\
\hline Site & 5 & 87.10 & 2.89 & $\leq 0.001$ \\
\hline Residual & 12 & 30.12 & & \\
\hline Location & 1 & 78.86 & 1.76 & $>0.05$ \\
\hline Residual & 16 & 44.88 & & \\
\hline \multicolumn{5}{|c|}{$\begin{array}{l}\text { Combined tissues (terrestrial markers } 18: 1 n-9 \text { and } \\
18: 2 n-6 \text { ) }\end{array}$} \\
\hline Site & 5 & 1.33 & 3.07 & $\leq 0.01$ \\
\hline Residual & 11 & 0.43 & & \\
\hline Location & 1 & 1.06 & 1.53 & $>0.05$ \\
\hline Residual & 15 & 0.69 & & \\
\hline \multicolumn{5}{|c|}{ Stable isotopes } \\
\hline \multicolumn{5}{|c|}{ Digestive gland } \\
\hline Site & 5 & 0.59 & 1.84 & $>0.05$ \\
\hline Residual & 12 & 0.32 & & \\
\hline Location & 1 & 1.47 & 4.45 & $<0.05$ \\
\hline Residual & 16 & 0.33 & & \\
\hline \multicolumn{5}{|l|}{ Muscle } \\
\hline Site & 5 & 0.17 & 2.62 & $<0.05$ \\
\hline Residual & 12 & 0.07 & & \\
\hline Location & 1 & 0.48 & 6.58 & $\leq 0.01$ \\
\hline Residual & 16 & 0.07 & & \\
\hline \multicolumn{5}{|l|}{ Gonad } \\
\hline Site & 5 & 0.83 & 3.79 & $\leq 0.01$ \\
\hline Residual & 12 & 0.22 & & \\
\hline Location & 1 & 1.51 & 4.55 & $<0.05$ \\
\hline Residual & 16 & 0.33 & & \\
\hline \multicolumn{5}{|c|}{ Combined tissues } \\
\hline Site & 5 & 1.59 & 2.63 & $<0.05$ \\
\hline Residual & 12 & 0.60 & & \\
\hline Location & 1 & 3.46 & 4.71 & $\leq 0.01$ \\
\hline Residual & 16 & 0.73 & & \\
\hline
\end{tabular}


Table 6. Comparison of the individual biochemical techniques in determining the correct sampling location of king scallops Pecten maximus based on multiple tissues. DNA based on non-quantitative analysis, fatty acids (FA, terrestrial only) and stable isotopes (SI) determined using canonical analysis of principal coordinates

\begin{tabular}{|lccc|}
\hline Biochemical technique & $\begin{array}{c}\text { \% Reference scallops correctly } \\
\text { classified as reference }\end{array}$ & $\begin{array}{c}\text { \% Farm scallops } \\
\text { correctly classified as farm }\end{array}$ & $\begin{array}{c}\text { Total \% correctly classified } \\
\text { to sample location }\end{array}$ \\
\hline DNA: gastric shield \& crystalline style & 77 & 100 & 88 \\
FA: digestive tissue, gonad \& muscle & 77 & 62 & 70 \\
SI: digestive tissue, gonad \& muscle & 66 & 100 & 83 \\
\hline
\end{tabular}

\section{Combining tracers}

CAP analysis indicated that using all the techniques together resulted in the highest overall correct classification of scallops $(85 \%)$ to their correct sampling location (Table 7). The detection of soya DNA in scallops was the best single determinant of farm vs. reference location, with $76.19 \%$ correct classification, compared to SI or terrestrial FAs. The addition of 1 of these techniques to soya detection did not increase overall correct classification success (Table 7). Using SI or FAs singularly showed poor correct classification; however, combining these 2 techniques increased correct classification to over $70 \%$ (Table 7). Overall, scallops had a higher chance of being correctly classified if they came from the reference location, with many farm scallops being misclassified (Table 7).

\section{DISCUSSION}

Our data suggests that we can trace organic effluents from aquaculture throughout one potential discharge pathway from entering (feed pellet) and leaving (fecal material) the fish pen to the sedimentation on the seafloor and uptake of the effluent in benthic species. The combined biochemical techniques can also determine both instantaneous uptake of the ef- fluents through feeding as well as assimilation over time, which provides higher order information on the importance of organic effluents in the benthic community.

As a first order analysis, all 3 techniques could be used to detect terrestrial components in the seston traps, suggesting we can separate reference and farm locations using these 3 techniques. The sediment proved more difficult to analyze than the material from the seston traps, since some of the markers did not yield significant differences between farm and references sites. Indeed, soya was successfully identified in the sediment and elevated terrestrial FA markers were found. However, these increases in the FA markers were not enough to differentiate farm sites, which displayed similar biochemical profiles to the reference locations. The similarity in the sediment could be due to the microbial processes that degrade feed pellet components, as organic waste material from aquaculture installation settles on the seafloor (Bannister et al. 2014, Valdemarsen et al. 2015). The speed of this process is dependent on both the biological and chemical environment of the sediment, combined with the microbial and macrofaunal consumption rate of organic matter, leading to the possibility of surface sediments being quickly reworked (Canuel \& Martens 1996, Bannister et al. 2014, Valdemarsen et al. 2015). Indeed, the Rataren farm is coastally located and exposed to strong tidal

Table 7. Comparison of using single or multiple biochemical techniques to determine the correct sampling location of king scallops Pecten maximus based on digestive tissue. SI: stable isotopes; FA: fatty acids (terrestrial only)

\begin{tabular}{|lccc|}
\hline $\begin{array}{l}\text { Biochemical } \\
\text { technique }\end{array}$ & $\begin{array}{c}\text { \% Reference scallops correctly } \\
\text { classified as reference }\end{array}$ & $\begin{array}{c}\text { \% Farm scallops correctly } \\
\text { classified as farm }\end{array}$ & $\begin{array}{c}\text { Total \% correctly classified } \\
\text { to sample location }\end{array}$ \\
\hline DNA & 83 & 66 & 76 \\
SI & 58 & 66 & 61 \\
FA & 58 & 55 & 57 \\
DNA \& SI & 83 & 66 & 76 \\
DNA \& FA & 83 & 66 & 76 \\
SI \& FA & 75 & 66 & 71 \\
DNA, SI \& FA & 83 & 88 & 85 \\
\hline
\end{tabular}


fluctuations and bottom currents (mean $8 \mathrm{~cm} \mathrm{~s}^{-1}$, max $41 \mathrm{~cm} \mathrm{~s}^{-1}$ ) (Johansen et al. 2016), which help to distribute the organic waste outfall from the farm. Combined degradation and current speeds could increase the overall area that is influenced by organic effluent. This may explain the similarities in the biochemistry of the sediment between farm and reference locations and why 2 of the scallops from a reference location showed a positive signal for soya. This surprising positive signal from the scallops at the reference site highlights the potential of soya to become a useful tool for tracing regional impacts, although further sampling and analysis is required to confirm the use of soya to detect organic effluent on a regional scale.

The 3 techniques showed promise in detecting terrestrial components from fin-fish effluent in the scallops collected at the farm sites. Soya was successfully identified in all the scallops collected near the Rataren farm, indicating that fin-fish effluent could represent a primary item in the diet of sampled scallops. This was further highlighted by the increase in $18: 1 \mathrm{n}-9$ and the decrease in $\delta^{15} \mathrm{~N}$ in the digestive tissues and the gonads of these same scallops compared to those from reference sites. The combination of all 3 techniques showed the highest overall correct classification of scallops back to their sampling location, compared to using any of the techniques individually or in paired combinations, indicating their complementary features. This also suggests that scallops in the area readily consume the organic effluents, since the DNA method suggests recent consumption while both FA and SI indicate assimilation over time.

Moreover, the 3 techniques showed complementary patterns of dilution along the discharge pathway, whereby the terrestrial signals of interest were higher in the source, i.e. feed pellet and fecal material, and decreased with dilution in the seston traps, sediment, and our endpoint, scallops (Fig. 2; soya based on non-quantifiable Cq-values, data not shown). While complementing each other, the 3 techniques have positive and negative aspects when applied individually to trace organic effluent.

The detection of soya DNA is a presence versus absence result. Since soya is not naturally present in the marine environment and its natural distribution does not include Norway, its presence is an indicator of organic effluents from aquaculture feed. Using a multiple copy gene like RuBisCO as the target allows this detection assay to be highly sensitive (Asahida et al. 1997), while the use of a probe in the TaqMan assay increases its specificity for the target gene. The presence and detection of soya, however, is dependent on the recent consumption of organic effluent from aquaculture feed, as the DNA is unable to bioaccumulate in an organism. Hence, the technique is limited to organisms having soya in their digestive tract that was consumed within the gut passage timeframe. The main advantage of the TaqMan assay is its high specificity to the target gene, but it can also be used as a quantitative estimate. In the current work, we used the TaqMan assay in a simple presence/absence format, using off-shore samples as a baseline for determining true negative samples. The data can therefore be interpreted as the percent, or ratio, of samples with a positive or negative signal (Lanzén et al. 2016). Although outside the scope of the current study, the assay can be further optimized together with appropriate standards to yield estimates of amounts of organic effluents in the discharge pathway (Troedsson et al. 2009). This will require careful assessment of the degradation and digestion properties of the RuBisCO gene under different environmental conditions, but will, once optimized, provide useful rates of discharge into different components of the environment adjacent to an aquaculture installation. There are several factors that can contribute to false negative results in our presence/absence mode of data interpretation that should be considered. Firstly, as previously mentioned, organic matter can be quickly reworked as it settles onto and is incorporated into the benthic environment (Bannister et al. 2014, Valdemarsen et al. 2015). In addition, humic and fulvic acids present in the sediment are well known inhibitors of the assay, which can contribute to lower efficiency in the PCR (Albers et al. 2013). Finally, due to the nature of sampling, scallops could not always be dissected immediately after collection, leaving digestion processes uncontrolled. This may impact the quantitative power of the assay (Troedsson et al. 2009).

FA and SI signatures can be used as long-term indicators of organic effluent exposure, being stored or incorporated into fauna tissues. In addition, they can help connect food web dynamics and biochemical shifts in the community (Budge \& Parrish 1998, Post 2002, Fredriksen 2003, Drazen et al. 2008). The terrestrial FA markers, 18:1n-9 and 18:2n-6, are found in low quantities in the marine environment. These markers are therefore used as aquaculture bioindicators in many species, since elevation of these 2 FAs are indicative of the consumption and accumulation of organic aquaculture effluents. For example, FAs have been used to show that shrimps close to fish farms incorporate organic effluents into 
their diet, indicating that they feed directly on the effluent or incorporate the FAs indirectly via feeding on impacted fauna (Olsen et al. 2012), and FA profiles in urchins indicate that these use aquaculture effluents as a trophic subsidy (White et al. 2017). Similarly, changes in SI and FA signatures have been found in blue mussels exposed to organic effluents from aquaculture (Redmond et al. 2010, Handå et al. 2012). Changes in SI can also be used to distinguish between farmed and wild salmon populations (Dempson \& Power 2004) due to differences in their diet.

The 3 biochemical techniques yielded complementary information on the uptake of organic effluents from aquaculture by benthic organisms such as scallops. While the DNA tracer yields data on the immediate ingestion, determined by the gut residence time of an organism, FA and SI tracers yield information on the cumulative assimilation of the organic effluent in tissue(s). Hence, we can obtain information on when organisms have consumed the organic effluent, and even an indication of whether this consumption is consistent over time. For example, differences in soya, $18: 1 \mathrm{n}-9$, and $\delta^{15} \mathrm{~N}$ were found in the digestive tissues of scallops, while $18: 1 \mathrm{n}-9$ and $\delta^{15} \mathrm{~N}$ were not significantly different in the muscle, a longer-term storage organ. The muscle was, however, the only tissue to show a difference in the overall FA profile and in the $\delta^{13} \mathrm{C}$ signature, indicating small longer-term changes in diet composition. Indeed, our data suggests that the use of all 3 biochemical techniques in combination provides the best results in determining whether scallops were collected from farm or reference locations.

The biochemical properties of the scallop tissues can be regulated by a combination of intrinsic (phylogeny, age, sex, reproductive cycle) and external factors (diet, temperature, salinity, depth) (GrahlNielsen et al. 2010). As such, the tissue type used can play an important role in establishing suitable tracing protocols. In this study, the digestive tissue (digestive gland, gastric shield, and crystalline style) was the most useful, largely due to it being the closest in contact with digested material, thereby showing recent biochemical profiles. Moreover, soya DNA signatures cannot be detected after the scallop has digested the compound. The muscle, on the other hand, tends to show long-term biochemical profiles. FA profiles in scallop muscle have low trophic markers, as the muscle reflects a combination of ingested food sources and endogenous processes, such as energy transfer to gonads for gametogenesis (Nerot et al. 2015). The accumulation of FAs into different tissues is quite different. Changes in the FA composi- tion have been found to take place within $28 \mathrm{~d}$ in the digestive gland and within $90 \mathrm{~d}$ in the mantle tissue of blue mussels Mytilus edulis near salmon farms (Handå et al. 2012). Similar results have been found in Atlantic croaker Micropogonias undulatus, with muscle showing $81 \mathrm{~d}$ and liver $46 \mathrm{~d}$ turnover after switching diets (S. Mohan et al. 2016). SI turnover times have also been determined within the same species, showing that $\delta^{15} \mathrm{~N}$ turnover is driven by growth in the muscle (27 to $54 \mathrm{~d}$ ) and metabolism in the liver (9 to $18 \mathrm{~d}$ ) (J. Mohan et al. 2016). Carbon isotope turnover in Atlantic croaker is primarily driven by growth in both tissues, with $30 \mathrm{~d}$ turnover in muscle and 30 to $50 \mathrm{~d}$ in liver, depending on diet quality (J. Mohan et al. 2016). The carbon incorporation index in scallops also differs among organs, being higher in the digestive gland, followed by gonad and muscle, although seasonal variations are stronger in the digestive gland and gonad (Paulet et al. 2006). The turnover times reported in these studies were determined from known dietary shifts and laboratory studies. The scallops from this study, however, were exposed to a natural mixed diet, influenced with traces of organic aquaculture effluents. Therefore, without knowing the biochemical properties of the scallops entire diet, it is difficult to determine whether the proportions of terrestrial markers we find are in direct proportion to what the scallops were exposed to, or have been modified due to feeding regimes, differences in uptake and season, or whether scallops were exposed to them for a long enough period. This is illustrated by the incorrect classification of farm scallops to reference sites using the multiple techniques. Although all the farm scallops were positive for the soya tracer, natural variations among individuals in FA and SI profiles impacted the success of scallop classification.

Gonzalez-Silvera et al. (2015) looked at the FA profiles of 18 macroinvertebrates associated with sea cages. Out of these 18 species, 5 were particularly sensitive to FA changes, while the remaining species showed little to no difference in their FA profiles. Differences between species were attributed to different feeding regimes and metabolic pathways (GonzalezSilvera et al. 2015). Scallops have a varied diet consisting primarily of phytoplankton, in addition to dissolved organic carbon, resuspended sediment, benthic algae, microheterotrophs, and bacteria (Nerot et al. 2015). Scallops have been characterized by their ability to store and postpone the use of energy, whereby energy stored as glycogen in the muscle and lipids in the digestive gland during spring and summer is used to sustain reproductive effort and 
maintenance during winter and periods of low food availability (Strohmeier et al. 2000, Paulet et al. 2006). Furthermore, scallops have been suggested to selectively assimilate nutrients from their diet and their isotopic fractionation between diet and tissue is predicted to be higher compared with other organisms (Lorrain et al. 2002).

The biomarker techniques used in this paper, DNA, FAs, and SI, are 3 of the potential techniques that could be used to determine the impacts of aquaculture. Other biomarkers could also be used in conjunction with these 3 techniques. For example, canthaxanthin is a carotenoid pigment used in many salmonid diets, and has been detected in blue mussels $M$. edulis and $M$. trossulus, and green sea urchins Strongylocentrotus droebachiensis exposed to aquaculture feed under laboratory conditions, as well as in the field, in urchins $100 \mathrm{~m}$ from a salmonid farm in Passamaquoddy Bay, New Brunswick (Graydon et al. 2012). Other diet supplements include medications. For example, the antibacterial substance oxolinic acid was used in the past and has been detected in wild fish, mussels, and crabs on the west coast of Norway (Samuelsen et al. 1992). Likewise, teflubenzuron, which is added to aquaculture feeds to combat louse infestations, was detected in $>50 \%$ of fauna sampled around a fish farm in Matre, Norway, after treatment (Samuelsen et al. 2015). Trace elements have also been used to assess regional impacts of aquaculture, and they can be used to assess both direct impacts of aquaculture facilities, e.g. copper used in antifouling paints (Chou et al. 2002, Solberg et al. 2002), and indirect effects resulting from operations and environmental changes, e.g. hypoxic or anoxic sediments (Chou et al. 2003, Kalantzi et al. 2013). Due to the nature of determining indirect impacts, a good understanding of the background levels of element concentrations in the environment as well as uptake pathways are required to effectively determine what any changes truly reflect. Biomarker techniques are just one method of monitoring organic effluent from aquaculture and can be used to complement other methods which measure environmental impacts, e.g. Modelling-Ongrowing fish farmMonitoring (Ervik et al. 1997, Hansen et al. 2001, Stigebrandt et al. 2004). While using a combination of techniques can increase labor and costs, the processing of samples is becoming relatively straightforward, with automated assays becoming readily available. Furthermore, the analysis of samples can be standardized for high throughput processing and routine monitoring of the environmental impact of aquaculture organic discharges. The costs involved in the different methods can vary between laboratories. Within this study, we have estimated the detection of soya DNA and SI to cost US\$8 per sample. FAs are more expensive at US\$44 per sample; however, recent method advancements are reducing the cost.

Biochemical techniques can be used not only as a tracer, but can also address potential concerns about the impacts terrestrial organic effluent may play in the marine environment, increasing their overall value. The application of mixing models to the SI ratio can be used to determine how much organic effluent is contributing to an individual's diet (Sarà 2007). Furthermore, FAs are biologically important: when exposed to diets with $>30 \%$ fish meal replacement with terrestrial sources, marine fauna have displayed decreased growth or become reproductively unviable (Yang et al. 2015, White et al. 2016). While scallops are not consuming organic effluent at the levels the organisms in these studies were exposed to, further research on other organisms which may be interacting with aquaculture needs to be carried out to better understand the influences organic effluents from aquaculture have on the environment.

This study shows the complementary nature of using 3 techniques to trace fin-fish effluent into the marine environment and its uptake into benthic organisms. A combination of techniques allowed the identification of scallops as being exposed to organic effluent both in the short term (DNA) and long term (FA and SI). These results can be used to further determine the accumulation of organic effluent in the local and regional environment surrounding fin-fish aquaculture, as we have here, or to complement existing monitoring programs.

Acknowledgements. This study was supported by the Norwegian Research Council (Project number 228871). The authors thank Camille White and Henrice Jansen for field assistance, the crew of RV 'Hans Brattström' (Institute of Marine Research, IMR), the Molecular Ecology Research Group at UNI Research for discussion and comments, laboratory technical staff (IMR) Sonnich Meier and Arve Fossen for guidance with the fatty acid analysis, Siri Aaserud Olsen and Penny Liebig for laboratory assistance, and Karen Gjertsen for construction of the map.

\section{LITERATURE CITED}

Albers CN, Jensen A, Bælum J, Jacobsen CS (2013) Inhibition of DNA polymerases used in Q-PCR by structurally different soil-derived humic substances. Geomicrobiol J 30:675-681

Asahida T, Yamashita Y, Kobayashi T (1997) Identification of consumed stone flounder, Kareius bicoloratus (Basilewsky), from the stomach contents of sand shrimp, Crangon affinis (De Haan) using mitochondrial DNA 
analysis. J Exp Mar Biol Ecol 217:153-163

Bannister RJ, Valdemarsen T, Hansen PK, Holmer M, Ervik A (2014) Changes in benthic sediment conditions under an Atlantic salmon farm at a deep, well-flushed coastal site. Aquacult Environ Interact 5:29-47

Bannister RJ, Johnsen IA, Hansen PK, Kutti T, Asplin L (2016) Near- and far-field dispersal modelling of organic waste from Atlantic salmon aquaculture in fjord systems. ICES J Mar Sci 73:2408-2419

Budge SM, Parrish CC (1998) Lipid biogeochemistry of plankton, settling matter and sediments in Trinity Bay, Newfoundland. II. Fatty acids. Org Geochem 29: 1547-1559

Canuel EA, Martens CS (1996) Reactivity of recently deposited organic matter: degradation of lipid compounds near the sediment-water interface. Geochim Cosmochim Acta 60:1793-1806

* Chou CL, Haya K, Paon LA, Burridge L, Moffatt JD (2002) Aquaculture-related trace metals in sediments and lobsters and relevance to environmental monitoring program ratings for near-field effects. Mar Pollut Bull 44: 1259-1268

Chou CL, Haya K, Paon LA, Moffatt JD (2003) Metals in the green sea urchin (Strongylocentrotus droebrachiensis [sic]) as an indicator for the near-field effects of chemical wastes from salmon aquaculture sites in New Brunswick, Canada. Bull Environ Contam Toxicol 70:948-956

* Crampton VO, Nanton DA, Ruohonen K, Skjervold PO, El Mowafi A (2010) Demonstration of salmon farming as a net producer of fish protein and oil. Aquacult Nutr 16: 437-446

* Dempson J, Power M (2004) Use of stable isotopes to distinguish farmed from wild Atlantic salmon, Salmo salar. Ecol Freshwat Fish 13:176-184

* Drazen JC, Phleger CF, Guest MA, Nichols PD (2008) Lipid, sterols and fatty acids of abyssal polychaetes, crustaceans, and a cnidarian from the northeast Pacific Ocean: food web implications. Mar Ecol Prog Ser 372:157-167

Duncan PF, Brand AR, Strand Ø, Foucher E (2016) The European scallop fisheries for Pecten maximus, Aequipecten opercularis, Chlamys islandica, and Mimachlamys varia. Dev Aquacult Fish Sci 40:781-858

Ervik A, Hansen PK, Aure J, Stigebrandt A, Johannessen P, Jahnsen $\mathrm{T}$ (1997) Regulating the local environmental impact of intensive marine fish farming I. The concept of the MOM system (Modelling-Ongrowing fish farmsMonitoring). Aquaculture 158:85-94

FAO (Food and Agriculture Organization of the United Nations) (2012) The state of world fisheries and aquaculture (SOFIA). FAO Fisheries and Aquaculture Department, Rome

Fernandez-Jover D, Jimenez JAL, Sanchez-Jerez P, BayleSempere J, Casalduero FG, Lopez FJM, Dempster T (2007) Changes in body condition and fatty acid composition of wild Mediterranean horse mackerel (Trachurus mediterraneus, Steindachner, 1868) associated to sea cage fish farms. Mar Environ Res 63:1-18

Fernandez-Jover D, Martinez-Rubio L, Sanchez-Jerez P, Bayle-Sempere JT and others (2011) Waste feed from coastal fish farms: a trophic subsidy with compositional side-effects for wild gadoids. Estuar Coast Shelf Sci 91: 559-568

Fredriksen S (2003) Food web studies in a Norwegian kelp forest based on stable isotope $\left(\delta^{13} \mathrm{C}\right.$ and $\left.\delta^{15} \mathrm{~N}\right)$ analysis. Mar Ecol Prog Ser 260:71-81
García-Sanz T, Ruiz J, Pérez M, Ruiz M (2011) Assessment of dissolved nutrients dispersal derived from offshore fish-farm using nitrogen stable isotope ratios $\left(\delta^{15} N\right)$ in macroalgal bioassays. Estuar Coast Shelf Sci 91: 361-370

Gonzalez-Silvera D, Izquierdo-Gomez D, Fernandez-Gonzalez V, Martínez-López FJ, López-Jiménez J, SanchezJerez P (2015) Mediterranean fouling communities assimilate the organic matter derived from coastal fish farms as a new trophic resource. Mar Pollut Bull 91: 45-53

* Grahl-Nielsen O, Jacobsen A, Christophersen G, Magnesen $\mathrm{T}$ (2010) Fatty acid composition in adductor muscle of juvenile scallops (Pecten maximus) from five Norwegian populations reared in the same environment. Biochem Syst Ecol 38:478-488

* Graydon CM, Robinson SM, Scheibling RE, Cooper JA (2012) Canthaxanthin as a potential tracer of salmon feed in mussels (Mytilus spp.) and sea urchins (Strongylocentrotus droebachiensis). Aquaculture 366-367:90-97

*Handå A, Min H, Wang X, Broch OJ, Reitan KI, Reinertsen $\mathrm{H}$, Olsen Y (2012) Incorporation of fish feed and growth of blue mussels (Mytilus edulis) in close proximity to salmon (Salmo salar) aquaculture: implications for integrated multi-trophic aquaculture in Norwegian coastal waters. Aquaculture 356-357:328-341

* Hansen PK, Ervik A, Schaanning M, Johannessen P, Aure J, Jahnsen T, Stigebrandt A (2001) Regulating the local environmental impact of intensive, marine fish farming. II. The monitoring programme of the MOM system (Modelling-Ongrowing fish farms-Monitoring). Aquaculture 194:75-92

*Holmer M, Marba N, Diaz-Almela E, Duarte CM, Tsapakis M, Danovaro R (2007) Sedimentation of organic matter from fish farms in oligotrophic Mediterranean assessed through bulk and stable isotope $\left(\delta^{13} \mathrm{C}\right.$ and $\left.\delta^{15} \mathrm{~N}\right)$ analyses. Aquaculture 262:268-280

Johansen C, Wahlvåg KR, Hestnes I, Reed JL, Kjerstad A (2016) Vurdering av strøm på grunnlag av 4 strømmålinger. SR-M-05116-RatarenI1216-ver01. Åkerblå AS, Sistranda

Kalantzi I, Black KD, Pergantis SA, Shimmield TM, Papageorgiou N, Sevastou K, Karakassis I (2013) Metals and other elements in tissues of wild fish from fish farms and comparison with farmed species in sites with oxic and anoxic sediments. Food Chem 141:680-694

* Lanzén A, Lekang K, Jonassen I, Thompson EM, Troedsson C (2016) High throughput metabarcoding of eukaryotic diversity for environmental monitoring of offshore oil drilling activities. Mol Ecol 25:4392-4406

Kekang K, Thompson EM, Troedsson C (2015) A comparison of DNA extraction methods for biodiversity studies of eukaryotes in marine sediments. Aquat Microb Ecol 75: 15-25

ㄴojen S, Spanier E, Tsemel A, Katz T, Eden N, Angel DL (2005) $\delta^{15} \mathrm{~N}$ as a natural tracer of particulate nitrogen effluents released from marine aquaculture. Mar Biol 148:87-96

* Lorrain A, Paulet YM, Chauvaud L, Savoye N, Donval A, Saout C (2002) Differential $\delta^{13} C$ and $\delta^{15} N$ signatures among scallop tissues: implications for ecology and physiology. J Exp Mar Biol Ecol 275:47-61

Martín-Díaz M, Blasco J, Sales D, DelValls T (2004) Biomarkers as tools to assess sediment quality: laboratory and field surveys. Trends Analyt Chem 23:807-818 
McGhie TK, Crawford CM, Mitchell IM, O'Brien D (2000) The degradation of fish-cage waste in sediments during fallowing. Aquaculture 187:351-366

Meier S, Mjøs SA, Joensen H, Grahl-Nielsen O (2006) Validation of a one-step extraction/methylation method for determination of fatty acids and cholesterol in marine tissues. J Chromatogr A 1104:291-298

Michener RH, Kaufman L (2007) Stable isotope ratios as tracers in marine food webs: an update. In: Michener R, Lajtha K (eds) Stable isotopes in ecology and environmental science, 2nd edn. Blackwell Publishing, Oxford, p 238-282

Mohan JA, Smith SD, Connelly TL, Attwood ET, McClelland JW, Herzka SZ, Walther BD (2016) Tissue-specific isotope turnover and discrimination factors are affected by diet quality and lipid content in an omnivorous consumer. J Exp Mar Biol Ecol 479:35-45

Mohan SD, Mohan JA, Connelly TL, Walther BD, McClelland JW (2016) Fatty acid biomarkers and tissue specific turnover: validation from a controlled feeding study in juvenile Atlantic croaker Micropogonias undulatus. J Fish Biol 89:2004-2023

Nejstgaard JC, Frischer ME, Raule CL, Gruebel R, Kohlberg KE, Verity PG (2003) Molecular detection of algal prey in copepod guts and fecal pellets. Limnol Oceanogr Methods 1:29-38

* Nejstgaard JC, Frischer ME, Simonelli P, Troedsson C and others (2008) Quantitative PCR to estimate copepod feeding. Mar Biol 153:565-577

Nerot C, Meziane T, Schaal G, Grall J, Lorrain A, Paulet YM, Kraffe E (2015) Spatial changes in fatty acids signatures of the great scallop Pecten maximus across the Bay of Biscay continental shelf. Cont Shelf Res 109:1-9

Olsen SA, Ervik A, Grahl-Nielsen O (2012) Tracing fish farm waste in the northern shrimp Pandalus borealis (Krøyer, 1838) using lipid biomarkers. Aquacult Environ Interact 2:133-144

Olsen BR, Troedsson C, Hadziavdic K, Pedersen RB, Rapp HT (2015) The influence of vent systems on pelagic eukaryotic micro-organism composition in the Nordic Seas. Polar Biol 38:547-558

* Paulet YM, Lorrain A, Richard J, Pouvreau S (2006) Experimental shift in diet $\delta^{13} \mathrm{C}$ : a potential tool for ecophysiological studies in marine bivalves. Org Geochem 37 : 1359-1370

Post DM (2002) Using stable isotopes to estimate trophic position: models, methods, and assumptions. Ecology 83 : 703-718

Redmond KJ, Magnesen T, Hansen PK, Strand Ø, Meier S (2010) Stable isotopes and fatty acids as tracers of the assimilation of salmon fish feed in blue mussels (Mytilus edulis). Aquaculture 298:202-210

Samuelsen OB, Lunestad BT, Husevåg B, Hølleland T, Ervik A (1992) Residues of oxolinic acid in wild fauna following medication in fish farms. Dis Aquat Org 12: 111-119

Samuelsen OB, Lunestad BT, Hannisdal R, Bannister R and others (2015) Distribution and persistence of the anti sealice drug teflubenzuron in wild fauna and sediments around a salmon farm, following a standard treatment. Sci Total Environ 508:115-121

Sanden M, Johannessen L, Berdal K, Sissener N, Hemre GI (2011) Uptake and clearance of dietary DNA in the intes- tine of Atlantic salmon (Salmo salar L.) fed conventional or genetically modified soybeans. Aquacult Nutr 17: e750-e759

* Sarà G (2007) Sedimentary and particulate organic matter: mixed sources for cockle Cerastoderma glaucum in a shallow pond, Western Mediterranean. Aquat Living Resour 20:271-277

* Sissener N, Julshamn K, Espe M, Lunestad B, Hemre GI, Waagbø R, Måge A (2013) Surveillance of selected nutrients, additives and undesirables in commercial Norwegian fish feeds in the years 2000-2010. Aquacult Nutr 19: 555-572

Skretting Norway (2015) Sustainability Report 2015. Skretting Norway, Stavangar. www.skretting.com

Solberg CB, Sæthre L, Julshamn K (2002) The effect of copper-treated net pens on farmed salmon (Salmo salar) and other marine organisms and sediments. Mar Pollut Bull 45:126-132

Stigebrandt A, Aure J, Ervik A, Hansen PK (2004) Regulating the local environmental impact of intensive marine fish farming. III. A model for estimation of the holding capacity in the Modelling-Ongrowing fish farm-Monitoring system. Aquaculture 234:239-261

Strohmeier T, Duinker A, Lie O (2000) Seasonal variations in chemical composition of the female gonad and storage organs in Pecten maximus (L.) suggesting that somatic and reproductive growth are separated in time. J Shellfish Res 19:741-748

* Symondson WOC (2002) Molecular identification of prey in predator diets. Mol Ecol 11:627-641

Troedsson C, Frischer ME, Nejstgaard JC, Thompson EM (2007) Molecular quantification of differential ingestion and particle trapping rates by the appendicularian Oikopleura dioica as a function of prey size and shape. Limnol Oceanogr 52:416-427

* Troedsson C, Simonelli P, Nägele V, Nejstgaard JC, Frischer ME (2009) Quantification of copepod gut content by differential length amplification quantitative PCR (dlaqPCR). Mar Biol 156:253-259

* Valdemarsen T, Hansen PK, Ervik A, Bannister RJ (2015) Impact of deep-water fish farms on benthic macrofauna communities under different hydrodynamic conditions. Mar Pollut Bull 101:776-783

*Van Biesen G, Parrish CC (2005) Long-chain monounsaturated fatty acids as biomarkers for the dispersal of organic waste from a fish enclosure. Mar Environ Res 60: 375-388

V Van Gestel CAM, Van Brummelen TC (1996) Incorporation of the biomarker concept in ecotoxicology calls for a redefinition of terms. Ecotoxicology 5:217-225

White CA, Dworjanyn SA, Nichols PD, Mos B, Dempster T (2016) Future aquafeeds may compromise reproductive fitness in a marine invertebrate. Mar Environ Res 122: 67-75

* White CA, Bannister RJ, Dworjanyn SA, Husa V, Nichols PD, Kutti T, Dempster T (2017) Consumption of aquaculture waste affects the fatty acid metabolism of a benthic invertebrate. Sci Total Environ 586:1170-1181

* Yang Q, Tan B, Dong X, Chi S, Liu H (2015) Effect of replacing fish meal with extruded soybean meal on growth, feed utilization and apparent nutrient digestibility of juvenile white shrimp (Litopenaeus vannamei). J Ocean Univ China 14:865-872 


\section{Appendix}

Table A1. Fatty acid profiles of farm effluent source and environmental samples ( $\%$, mean $\pm \mathrm{SE}$; single values for fecal material). SFA, MUFA, PUFA: saturated, monounsaturated, and polyunsaturated fatty acids, respectively. nd: not detected

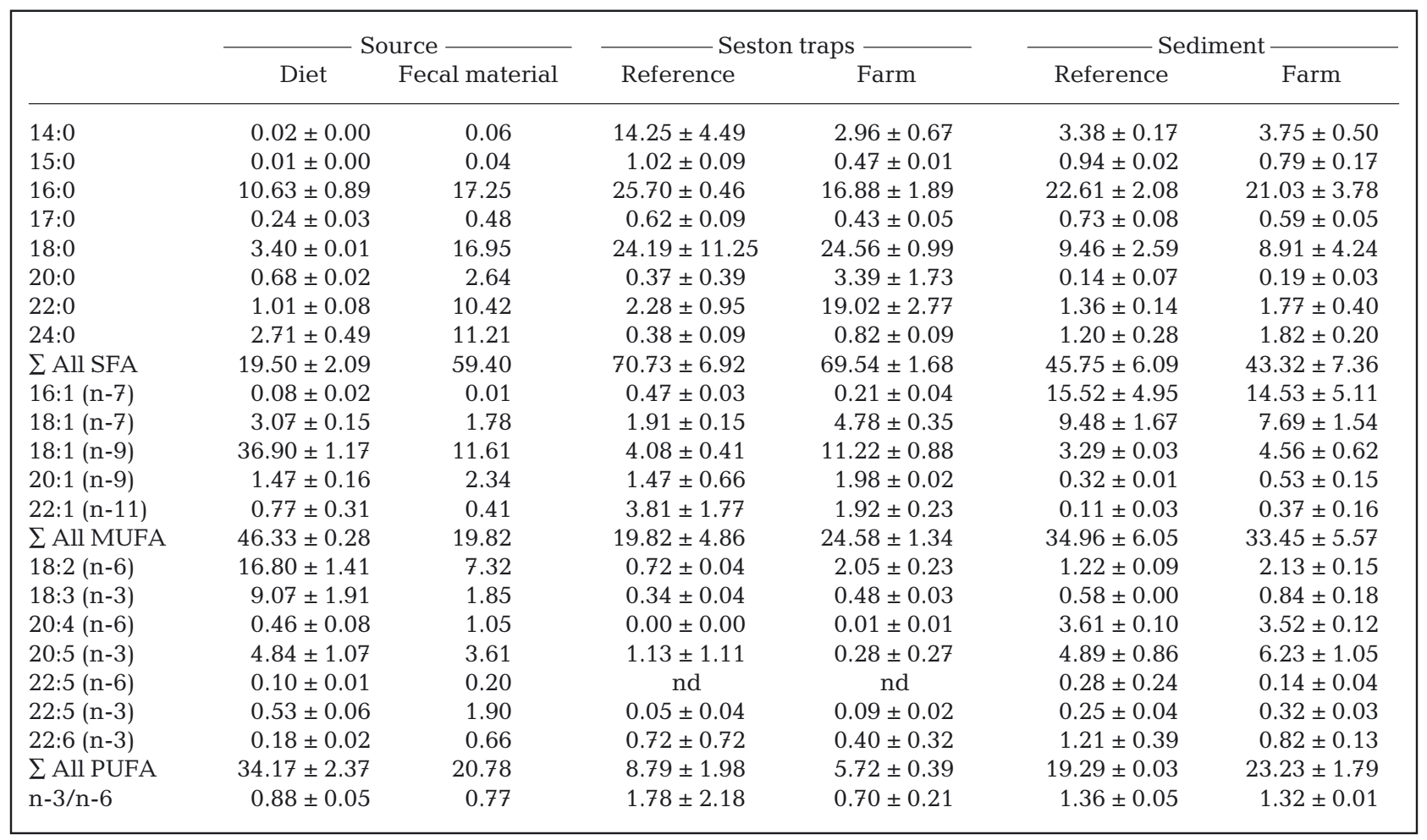

Table A2. Fatty acid profiles of king scallop Pecten maximus tissues (\%, mean \pm SE). nd: not detected

\begin{tabular}{|c|c|c|c|c|c|c|}
\hline & \multicolumn{2}{|c|}{ Digestive tissue } & \multicolumn{2}{|c|}{$\longrightarrow$ Gonad } & \multirow{2}{*}{\multicolumn{2}{|c|}{ Muscle $\longrightarrow$}} \\
\hline & Reference & Farm & Reference & Farm & & Farm \\
\hline $14: 0$ & $3.59 \pm 0.08$ & $3.42 \pm 0.09$ & $2.95 \pm 0.27$ & $2.84 \pm 0.22$ & $2.42 \pm 0.05$ & $2.40 \pm 0.11$ \\
\hline $15: 0$ & $0.44 \pm 0.01$ & $0.42 \pm 0.01$ & $0.56 \pm 0.03$ & $0.54 \pm 0.02$ & $0.72 \pm 0.02$ & $0.73 \pm 0.02$ \\
\hline $16: 0$ & $17.90 \pm 0.62$ & $17.75 \pm 0.22$ & $19.39 \pm 0.36$ & $18.71 \pm 0.27$ & $19.26 \pm 0.21$ & $19.76 \pm 0.17$ \\
\hline $17: 0$ & $0.48 \pm 0.03$ & $0.46 \pm 0.02$ & $0.97 \pm 0.04$ & $0.90 \pm 0.02$ & $1.09 \pm 0.04$ & $1.04 \pm 0.08$ \\
\hline 18:0 & $3.22 \pm 0.19$ & $2.93 \pm 0.21$ & $5.21 \pm 0.28$ & $4.39 \pm 0.42$ & $5.48 \pm 0.12$ & $6.05 \pm 0.12$ \\
\hline $20: 0$ & $0.13 \pm 0.01$ & $0.18 \pm 0.01$ & $0.06 \pm 0.01$ & $0.09 \pm 0.01$ & nd & nd \\
\hline $22: 0$ & $0.14 \pm 0.01$ & $0.18 \pm 0.01$ & $0.35 \pm 0.02$ & $0.38 \pm 0.02$ & $0.38 \pm 0.02$ & $0.39 \pm 0.03$ \\
\hline $24: 0$ & $0.06 \pm 0.00$ & $0.08 \pm 0.01$ & $0.16 \pm 0.01$ & $0.16 \pm 0.02$ & $0.21 \pm 0.01$ & $0.20 \pm 0.01$ \\
\hline$\sum$ All SFA & $27.15 \pm 0.70$ & $26.56 \pm 0.28$ & $31.28 \pm 0.46$ & $29.61 \pm 0.49$ & $31.21 \pm 0.35$ & $32.17 \pm 0.24$ \\
\hline $16: 1(\mathrm{n}-7)$ & $14.64 \pm 0.46$ & $14.02 \pm 0.38$ & $5.86 \pm 0.21$ & $5.44 \pm 0.16$ & $3.09 \pm 0.12$ & $2.96 \pm 0.16$ \\
\hline $18: 1(n-7)$ & $4.81 \pm 0.09$ & $4.73 \pm 0.11$ & $4.53 \pm 0.16$ & $4.35 \pm 0.11$ & $2.84 \pm 0.10$ & $2.69 \pm 0.22$ \\
\hline 18:1 (n-9) & $2.56 \pm 0.15$ & $3.28 \pm 0.13$ & $2.30 \pm 0.08$ & $3.07 \pm 0.16$ & $1.17 \pm 0.04$ & $1.34 \pm 0.11$ \\
\hline 20:1 (n-9) & $0.76 \pm 0.05$ & $1.06 \pm 0.07$ & $0.72 \pm 0.05$ & $0.94 \pm 0.06$ & $1.14 \pm 0.05$ & $1.32 \pm 0.12$ \\
\hline $22: 1(n-11)$ & $0.22 \pm 0.02$ & $0.37 \pm 0.03$ & $0.11 \pm 0.01$ & $0.22 \pm 0.04$ & $0.07 \pm 0.01$ & $0.12 \pm 0.01$ \\
\hline$\sum$ All MUFA & $25.69 \pm 0.45$ & $26.20 \pm 0.34$ & $16.51 \pm 0.32$ & $17.14 \pm 0.44$ & $10.86 \pm 0.27$ & $10.95 \pm 0.54$ \\
\hline $18: 2(n-6)$ & $2.24 \pm 0.07$ & $2.40 \pm 0.05$ & $1.12 \pm 0.05$ & $1.32 \pm 0.06$ & $0.73 \pm 0.03$ & $0.71 \pm 0.06$ \\
\hline $18: 3(n-3)$ & $1.17 \pm 0.06$ & $1.19 \pm 0.04$ & $0.68 \pm 0.07$ & $0.81 \pm 0.07$ & $0.36 \pm 0.02$ & $0.32 \pm 0.03$ \\
\hline $20: 4(n-6)$ & $0.86 \pm 0.02$ & $0.77 \pm 0.03$ & $1.83 \pm 0.06$ & $1.69 \pm 0.05$ & $2.02 \pm 0.05$ & $1.72 \pm 0.15$ \\
\hline $20: 5(n-3)$ & $22.69 \pm 0.63$ & $23.07 \pm 0.51$ & $19.73 \pm 0.40$ & $20.30 \pm 0.42$ & $17.17 \pm 0.36$ & $16.58 \pm 0.48$ \\
\hline $22: 5(n-6)$ & $0.16 \pm 0.01$ & $0.15 \pm 0.00$ & $0.32 \pm 0.02$ & $0.29 \pm 0.03$ & $0.49 \pm 0.02$ & $0.44 \pm 0.04$ \\
\hline $22: 5(\mathrm{n}-3)$ & $0.45 \pm 0.02$ & $0.42 \pm 0.01$ & $1.02 \pm 0.05$ & $0.75 \pm 0.11$ & $1.19 \pm 0.03$ & $1.05 \pm 0.08$ \\
\hline $22: 6(n-3)$ & $7.61 \pm 0.37$ & $7.14 \pm 0.17$ & $15.16 \pm 0.37$ & $15.85 \pm 0.40$ & $22.04 \pm 0.56$ & $21.56 \pm 0.54$ \\
\hline$\sum$ All PUFA & $46.50 \pm 0.68$ & $46.39 \pm 0.37$ & $49.96 \pm 0.62$ & $51.10 \pm 0.50$ & $50.57 \pm 0.64$ & $48.44 \pm 0.69$ \\
\hline$n-3 / n-6$ & $8.59 \pm 0.21$ & $8.38 \pm 0.14$ & $9.30 \pm 0.33$ & $9.08 \pm 0.27$ & $9.88 \pm 0.22$ & $12.10 \pm 2.35$ \\
\hline
\end{tabular}

